\title{
4,7-Dichloro[1,2,5]oxadiazolo[3,4-d]pyridazine 1-oxide
}

\author{
Timofey Chmovzh ${ }^{1}$, Ekaterina Knyazeva ${ }^{1,2}$, Vadim Popov ${ }^{2}$ and Oleg Rakitin 1,2,* (D) \\ 1 N. D. Zelinsky Institute of Organic Chemistry Russian Academy of Sciences, 47 Leninsky Prospekt, \\ Moscow 119991, Russia; tim1661@yandex.ru (T.C.); katerina_knyazev@ioc.ac.ru (E.K.) \\ 2 Nanotechnology Education and Research Center, South Ural State University, 76 Lenina Avenue, \\ Chelyabinsk 454080, Russia; popov.ioc@gmail.com \\ * Correspondence: orakitin@ioc.ac.ru; Tel.: +7-499-135-5327
}

Received: 2 February 2018; Accepted: 16 February 2018; Published: 18 February 2018

\begin{abstract}
Dihalogenated derivatives of $[1,2,5]$ chalcogenadiazolo[3,4- $d]$ pyridazines are of interest as precursors for both photovoltaic materials and biologically active compounds. In this communication, 4,7-dichloro[1,2,5] oxadiazolo[3,4-d]pyridazine 1-oxide was prepared via the reaction of 3,6-dichloro-5-nitropyridazin-4-amine with oxidizing agents; the best yield of the target compound was achieved in the reaction with (diacetoxyiodo)benzene in benzene by heating at reflux for two hours. The structure of the newly synthesized compound was established by means of ${ }^{13} \mathrm{C}-\mathrm{NMR}$ and IR spectroscopy, mass-spectrometry and elemental analysis.
\end{abstract}

Keywords: [1,2,5]oxadiazolo[3,4-d]pyridazine 1-oxide; pyridazine; oxidation

\section{Introduction}

1,2,5-Chalcogenadiazoles fused with either benzene or heterocyclic rings have been found to be important central building blocks in the synthesis of photovoltaic materials [1-3]. Although 2,1,3-benzochalcogenadiazoles have been intensively investigated, their heterocyclic analogues are less known $[4,5]$. Within this type of heterocycles, special attention has been paid to their dihalogenated derivatives due to their potential in the synthesis of dyes to the dye-sensitized solar cells (DSSCs) [6]. To the best of our knowledge 4,7-dichloro[1,2,5]thiadiazolo[3,4-d]pyridazine is the only known dihalo[1,2,5]chalcogenadiazolo[3,4- $d]$ pyridazine [7], although no structure confirmation (such as spectral and analytical data or reactivity) was provided. Herein, we report the synthesis of 4,7-dichloro[1,2,5] oxadiazolo[3,4-d]pyridazine 1-oxide. This compound may be of interest as starting material for the preparation of various photovoltaic materials as well as biologically active compounds since it was shown that the fusion of 1,2,5-oxadiazole $N$-oxide (furoxan) ring to nitrogen heterocycle can substantially increase the biological activity [8].

\section{Results and Discussion}

Recently, we have shown that [1,2,5]oxadiazolo[3,4-c]pyridine 3-oxide is available via the oxidation of 4-amino-3-nitropyridine with (diacetoxyiodo)benzene ( $\left.\mathrm{PhI}(\mathrm{OAc})_{2}\right)$, PIDA or [bis(trifluoroacetoxy)iodo]benzene $\left(\mathrm{PhI}\left(\mathrm{OC}(\mathrm{O}) \mathrm{CF}_{3}\right)_{2}\right)$, PIFA [9]. Herein, we examined 3,6-dichloro-5-nitropyridazin-4-amine $\mathbf{1}$ in the reaction both with PIDA and PIFA (Scheme 1).

We found that the nature of the oxidizing agent, solvent and the reaction temperature significantly influenced the yield of desired dichlorinated product 2 . The results were summarized in Table 1 . The treatment of pyridazine $\mathbf{1}$ with PIDA in benzene at room temperature gave no reaction, while heating the reaction mixture at reflux led to the formation of target bicycle 2 , but this compound was found to be unstable at this temperature. The best yield was achieved after refluxing in benzene for $2 \mathrm{~h}$ (Entry 2). The use of other solvents with higher (toluene, Entry 4), or lower (acetone, Entry 6) boiling 
points did not improve the results. Unexpectedly, PIFA, known as a stronger oxidizing agent, reacted with pyridine 1 more slowly (Entry 7).<smiles>Nc1c(Cl)nnc(Cl)c1[N+](=O)[O-]</smiles>

Scheme 1. Synthesis of 4,7-dichloro[1,2,5] oxadiazolo[3,4- $d$ ]pyridazine 1-oxide 2.

Table 1. Reaction of 3,6-dichloro-5-nitropyridazin-4-amine 1 with oxidizing agents.

\begin{tabular}{ccccccc}
\hline \multirow{2}{*}{ Entry } & \multirow{2}{*}{ Solvent } & Reagent & Temperature, ${ }^{\circ} \mathbf{C}$ & \multirow{2}{*}{ Time, $\mathbf{h}$} & \multicolumn{2}{c}{ Yield, $\mathbf{\%}$} \\
\cline { 5 - 7 } & & & & & $\mathbf{2}$ & $\mathbf{1}$ \\
\hline 1 & benzene & PIDA & 80 & 2 & 45 & 30 \\
2 & benzene & PIDA & 80 & 3 & 50 & 5 \\
3 & benzene & PIDA & 80 & 2 & 10 & 20 \\
4 & toluene & PIDA & 110 & 2 & 55 & 8 \\
5 & toluene & PIDA & 80 & 2 & 15 & 25 \\
6 & acetone & PIDA & 56 & 2 & 5 & 70 \\
7 & benzene & PIFA & 80 & & & 5 \\
\hline
\end{tabular}

The structure of furoxan 2 was strictly confirmed by means of ${ }^{13} \mathrm{C}-\mathrm{NMR}$ and IR spectroscopy, mass-spectrometry and elemental analysis.

\section{Experimental Section}

\subsection{General Information}

3,6-Dichloro-5-nitropyridazin-4-amine 1 was prepared according to the published method by nitration of 3,6-dichloropyridazin-4-amine with a mixture of nitric and sulfuric acids [10] and characterized by spectral data. Elemental analysis was performed on Perkin Elmer 2400 Elemental Analyser. Melting point was determined on a Kofler hot-stage apparatus and is uncorrected. ${ }^{13} \mathrm{C}-\mathrm{NMR}$ spectra were taken with a Bruker AM-300 machine (at frequency of $75.5 \mathrm{MHz}$, respectively) in $\mathrm{CD}_{2} \mathrm{Cl}_{2}$ solutions, with TMS as the standard. MS spectra $(\mathrm{EI}, 70 \mathrm{eV})$ was obtained with a Finnigan MAT INCOS 50 instrument. IR spectrum was measured with a Specord M-80 instrument in KBr pellet.

\subsection{Synthesis of 4,7-dichloro[1,2,5]oxadiazolo[3,4-d]pyridazine 1-oxide 2}

A solution of 3,6-dichloro-5-nitropyridazin-4-amine (1) (35 $\mathrm{mg}, 0.16 \mathrm{mmol}$ ) and (diacetoxyiodo)benzene $(57 \mathrm{mg}, 0.17 \mathrm{mmol})$ in benzene $(2 \mathrm{~mL})$ was heated under reflux with stirring for $2 \mathrm{~h}$. The mixture was cooled to room temperature and the solvent was removed under reduced pressure. $\mathrm{CH}_{2} \mathrm{Cl}_{2}(15 \mathrm{~mL})$ was added to the residue, the organic phase was washed with saturated aqueous $\mathrm{NaHCO}_{3}$, and dried over $\mathrm{MgSO}_{4}$. The solvent was removed under reduced pressure. The residue was subjected to column chromatography on silica gel (Silica gel Merck 60, eluent: petroleum ether- $\mathrm{CH}_{2} \mathrm{Cl}_{2}, 1: 1$, and $\mathrm{CH}_{2} \mathrm{Cl}_{2}$ ). Yield $21 \mathrm{mg}(65 \%)$, yellow crystals, $\mathrm{mp} 115-118{ }^{\circ} \mathrm{C}$. $\mathrm{R}_{\mathrm{f}}=0.7\left(\mathrm{CH}_{2} \mathrm{Cl}_{2}\right)$. IR spectrum, $v, \mathrm{~cm}^{-1}: 1640(\mathrm{C}=\mathrm{N}), 1508,1442,1396,1367,1345,1236,987,956,708$, 628; ${ }^{13} \mathrm{C}-\mathrm{NMR}$ (ppm): $\delta 106.9$ (C=N=O, Pyr); 142.5 (C=N, Pyr); 143.8 (C-Cl, Pyr); 148.2 (C-Cl, Pyr); LRMS, $m / z(\%): 210[\mathrm{M}+4]^{+}(3), 208[\mathrm{M}+2]^{+}(16), 206[\mathrm{M}]^{+}(28), 192(10), 190(21), 176(10), 162(11)$, 160 (25), 117 (100), 99 (30), 47(25). Anal. Calcd. for $\mathrm{C}_{4} \mathrm{Cl}_{2} \mathrm{~N}_{4} \mathrm{O}_{2}$ : C 23.21; N 27.07; found: $\mathrm{C}, 23.15 ; \mathrm{N}$, $27.28 \%$. 
Supplementary Materials: The following are available online, ${ }^{13} \mathrm{C}-\mathrm{NMR}$, IR and mass-spectra for the compounds $\mathbf{1}$ and $\mathbf{2}$ are available online at www.mdpi.com/1422-8599/2018/1/M982/s1.

Acknowledgments: This work was financially supported by the Ministry of Education and Science of the Russian Federation (grant no. 4.9651.2017/BP). V. P. is grateful to South Ural State University.

Conflicts of Interest: The authors declare no conflict of interest.

\section{References}

1. $\mathrm{Wu}, \mathrm{Y}$; $\mathrm{Zhu}, \mathrm{W}$. Organic sensitizers from $\mathrm{D}-\pi-\mathrm{A}$ to $\mathrm{D}-\mathrm{A}-\pi-\mathrm{A}$ : effect of the internal electron-withdrawing units on molecular absorption, energy levels and photovoltaic performances. Chem. Soc. Rev. 2013, 42, 2039-2058. [CrossRef] [PubMed]

2. Zhang, X.; Grätzel, M.; Hua, J. Donor design and modification strategies of metal-free sensitizers for highly-efficient n-type dye-sensitized solar cells. Front. Optoelectron. 2016, 9, 3-35. [CrossRef]

3. Knyazeva, E.A.; Rakitin, O.A. Influence of structural factors on the photovoltaic properties of dye-sensitized solar cells. Russ. Chem. Rev. 2016, 85, 1146-1183. [CrossRef]

4. Konstantinova, L.S.; Knyazeva, E.A.; Rakitin, O.A. Recent Developments in the Synthesis and Applications of 1,2,5-Thia- and Selenadiazoles. A Review. Org. Prep. Proc. Int. 2014, 46, 475-544. [CrossRef]

5. Parker, T.C.; Patel, D.G.; Moudgil, K.; Barlow, S.; Risko, C.; Brédas, J.-L.; Reynolds, J.R.; Marder, S.R. Heteroannulated acceptors based on benzothiadiazole. Mater. Horiz. 2015, 2, 22-36. [CrossRef]

6. Knyazeva, E.A.; Rakitin, O.A. 4,7-Dibromo-substituted 2,1,3-benzothia(selena, oxa)diazoles and $[1,2,5]$ thia(selena)diazolo[3,4-c]pyridine as building blocks in solar cells components (microreview). Chem. Heterocycl. Comp. 2017, 53, 855-857. [CrossRef]

7. Marn, J.; Stanovnik, B.; Tishler, M. Pyridazines. XI. Reactions of 1,2,5-thiadiazolo[3,4-d]pyridazines. Croatica Chem. Acta 1971, 43, 101-105.

8. Makhova, N.N.; Rakitin, O.A. Furoxans fused with heterocycles as promising donors and precursors for nitric oxide donors (microreview). Chem. Heterocycl. Comp. 2017, 53, 849-851. [CrossRef]

9. Chmovzh, T.N.; Konstantinova, L.S.; Knyazeva, E.A.; Struchkova, M.I.; Rakitin, O.A. A short and safe method for the synthesis of [1,2,5] oxadiazolo[3,4-c]pyridine. Chem. Heterocycl. Comp. 2015, 51, $203-204$. [CrossRef]

10. Tahri, A.; Jonkers, T.H.M.; Raboisson, P.J.-M.B.; Demin, S.D. Quinoxalines and dihydroquinoxalins as respiratory syncytial virus antiviral agents. WO2014/114776, 2014.

(C) 2018 by the authors. Licensee MDPI, Basel, Switzerland. This article is an open access article distributed under the terms and conditions of the Creative Commons Attribution (CC BY) license (http:/ / creativecommons.org/licenses/by/4.0/). 